\title{
COMMONWEALTH AGRICULTURAL BUREAUX
}

The journals and occasional publications of the two Institutes and ten Bureaux in this organization provide an introduction to the world literature on all aspects of crop, grassland and animal husbandry, horticulture, dairy science, forestry, and the health of crops and animals.

\section{RECENT TECHNICAL COMMUNICATIONS}

\section{THE ESTABLISHMENT OF VEGETATION ON INDUSTRIAL WASTE LAND}

By R. O. WHyTE and J. W. B. SISAM

1950. ros.

This publication is the ultimate outcome of a study of the problems and techniques of reclamation of industrial waste land by the study of vegetation. The great majority of the information has been collected from unpublished sources from those who have undertaken the work or are interested in its execution.

\section{THE PRODUCTION AND UTILIZATION OF SILAGE}

A REVIEW OF WORLD LITERATURE IN ABSTRACTS 1950. Ios.

While it has not been possible to produce a balanced review of the whole problem, abstracts of all papers and other publications which have appeared over a period of some 15 to 20 years have been brought together, in order that this may serve as a reference book to the very extensive literature.

\section{FIELD TRIALS: PART II. ANALYSIS OF COVARIANCE}

$$
\text { By J. WISHART }
$$

Written by the author of Field trials: Their lay-out and Statistical Analysis, published in 1940 and since reprinted, the present bulletin carries the subject into the domain of those topics which are commonly referred to as comprising the "Analysis of Covariance". The object is to assist the investigator still further in reducing his experimental errors by pointing out how observations made on variates other than those in which he is specifically interested may be used by means of a special arithmetical technique, in the statistical analysis of his results.

All correspondence regarding the above and other publications should be addressed to

COMMONWEALTH AGRICULTURAL BUREAUX

Central Sales Branch, Penglais, Aberystwyth, Great Britain

The Journal of Agricultural Science is issued in quarterly parts of about 120 pages with plates and figures, four parts constituting a volume.

Volumes XVI-XX (1926-1930) are out of print. Quotations can be given for other back volumes and parts.

Quotations can also be given for buckram binding cases. (Suspended.)

Papers for publication should be typewritten or written in a very legible hand, and may be sent to Dr J. Hammond, School of Agriculture, Cambridge, or to the associate Editors. Other communications should be addressed to the University Press, Cambridge. form:

Bibliography should be given under the heading of "References" in the following

Surname of authors (in alphabetical order), initials, date of publication (in brackets), title of Journal (abbreviated according to the World List $_{\text {is }}$ Scientific Periodicals), volume and pages of reference. In the text a reference should be quoted by the author's name and date (in brackets).

All names of Journals and books should be in italics.

Contributors will receive twenty-five copies of their papers free.

The subscription price for each volume, payable in advance, is $40 \mathrm{~s}$. net per volume (post free); single numbers 15s. net. Subscriptions may be sent to any Bookseller, or to The Cambridge University Press, Bentley House, 200 Euston Road, London, N.W.1.

Finquiries from the U.S.A. should be addressed to the Cambridge University Press American Branch, 51 Madison Avenue, New York, 10. 


\section{CONTENTS}

Callow, E. H. Comparative studies of meat. IV. Rates of fattening in relation to the deposition of fat and protein in the fatty and muscular tissues of meat carcasses. (With Four Text-figures)

BeLl, G. D. H. Investigations in the Triticinae. I. Colchicine techniques for chromosome doubling in interspecific and intergeneric hybridization. (With Plates 1 and 2)

Griffiths, D. J. The liability of seed crops of perennial ryegrass (Lolium perenne) to contamination by windborne pollen. (With Eleven Text-figures)

Duckworth, J., Naftalin, J. M. and Dalgarno, A. C. The digestibility of linseed oil and mutton fat by chicks . . . . . .

Carpenter, K. J. and Duckworth, J. The nutritive value of herring 'alkali-reduction' meal for chicks . . . . . . .

Barnetr, A. John G. and MrLere, T. B. Studies on the soluble nitrogen content of dried samples of grass silage. (With Four Text-figures) .

INGHAM, G. The mineral content of air and rain and its importance to agriculture

Blackman, G. E. and Roberts, H. A. Studies in selective weed control. I. The control of annual weeds in winter wheat . . . .

Blackman, G. E. and Roberts, H. A. Studies in selective weed control. II. The control of annual weeds in spring cereals . . . .

ROTHSCHID, LoRD. Electrical measurement of bull sperm activity. Comparison with visual assessment . . . . . .

Braude, R., Mrtchell, K. G. and Robinson, K. L. The value of Australian sorghum for fattening pigs . . . . . .

Armstrong, D. G., Cook, H. and Thomas, B. The lignin and cellulose contents of certain grassland species at different stages of growth .

EDwards, JosepH. Factors influencing the relationship between the secretion of milk and butterfat. (With Sixteen Text-figures) . .

Frndlay, J. D. and YANG, S. H. The sweat glands of Ayrshire cattle. (With Plates 3-7 and One Text-figure)

Alloberry, E. C. On the capillary forces in an idealized soil. (With Six Text-figures)

Hart, D. S. Photoperiodicity in Suffolk sheep. (With Four Text-figures)

Dawson, F. L. M. The microbial content and morphological character of the normal bovine uterus and oviduct. (With Plate 8)

84

93

100

126

134

143

DrdCe, Edward and Wricox, James Stuart. The hydrolytic examination of plant cellulose isolated by the method of Druce and Willcox

Jewitr, T. N. Field nitrates in Gezira soil. (With Two Text-figures) .

BARNES, T. W. The formation of nitrates in soil following various crop rotations

MannING, H. L. Confidence limits of expected monthly rainfall. (With Four Text-figures) . $\quad . \quad$. . . . . . .

FuUx, D. S. The effect of undernutrition before calving on the quantity and composition of milk produced by two-year-old heifers. (With Two Text-figures)

OWEN, O., Rogers, D. W. and Wrissor, G. W. The nitrogen status of soils. Part I. The nitrification of some nitrogenous fertilizers. (With Three Text-figures) .

150

157

160

166

169

177

185

OWEN, O. and WInsor, G. W. The nitrogen status of soils. Part II. The effect of levels of application on the nitrification of some nitrogenous fertilizers. (With Three Text-figures)

Printed in Great Britain at the University Press, Cambridge

(Brooke Orutchley, University Printer) 